\title{
Students' science attitudes, beliefs, and context: associations with science and chemistry aspirations
}

\author{
Tamjid Mujtaba, Richard Sheldrake, Michael J. Reiss and Shirley Simon \\ UCL Institute of Education, University College London, London, England
}

\begin{abstract}
There is a widespread concern that relatively few students, especially those from disadvantaged backgrounds, continue to study chemistry and other science subjects after compulsory education. Yet it remains unclear how different aspects of students' background and home context, their own attitudes and beliefs, and their experiences of particular teaching approaches in school might limit or facilitate their studying aspirations; concurrently, less research has specifically focused on and surveyed disadvantaged students. In order to gain more insight, 4780 students were surveyed, covering those in Year 7 (age 11-12 years) and in Year 8 (age 12-13) from schools in England with high proportions of those from disadvantaged backgrounds. Predictive modelling highlighted that the students' aspirations to study non-compulsory science in the future, and to study the particular subject of chemistry, were strongly associated with their extrinsic motivation towards science (their perceived utility of science, considered as a means to gain particular careers or skills), their intrinsic interest in science, and their engagement in extra-curricular activities. Additionally, their selfconcept beliefs (their confidence in their own abilities in science), some teaching approaches, and encouragement from teachers and family alongside family science capital had smaller but still relevant associations.
\end{abstract}

Keywords: aspirations, teaching approaches, self-concept, extrinsic motivation, intrinsic, encouragement, science capital 


\section{Students' science attitudes, beliefs, and context: associations with science and chemistry aspirations}

\section{Introduction}

Science policy and science education in England, and in other countries, remains concerned over the numbers of students who do not continue to study science subjects once they become non-compulsory (ACOLA, 2013; National Science and Technology Council, 2013; Royal Society, 2014). More specifically, concerns remain over the need to understand and address inequity and other differences in studying intentions and choices that associate with, or potentially follow from, students' backgrounds and contexts (Bosworth, Lyonette, Wilson, Bayliss, \& Fathers, 2013; British Academy, 2015; Institute of Physics, 2014; Royal Society of Chemistry, 2014; Wilson, Beaven, May-Gillings, Hay, \& Stevens, 2014). For example, fewer students from disadvantaged backgrounds choose to study non-compulsory science subjects, especially chemistry and physics (Elias, Jones, \& McWhinnie, 2006; Springate, Harland, Lord, \& Wilkin, 2008).

Across many research studies in England and other countries, students' attitudes towards science, such as their interest in science and perceived utility of science, and their motivational beliefs, such as their confidence in their own abilities, together with their own attainment, have closely associated with their intentions and choices (Bøe \& Henriksen, 2015; Regan \& DeWitt, 2015). It remains less clear how such attitudes and beliefs might be facilitated or constrained by students' background or context, and how these different factors may concurrently influence students' aspirations. For example, teaching approaches and classroom experiences in secondary school have been found to influence students' interest in science and their other attitudes, but any direct associations with students' choices remains somewhat unclear (Abrahams, 2009; Hampden-Thompson \& Bennett, 2013; Wang, 2012). Essentially, there remains uncertainty about which attitudes and aspects of life, and which teaching approaches and/or classroom experiences, associate with students' science intentions and so could be used to inspire more students to study science subjects.

Accordingly, the research presented here considered what associated with students' science aspirations, providing a new perspective through focusing on a sample of disadvantaged students (who may or may not consider their studying choices in the same way as advantaged students), drawn from schools where students historically have shown lower 
attainment and with catchments that have a greater than average number of families from low socio-economic backgrounds (Department of Education, 2016). The research aimed to distinguish the relative influences of students' background, aspects of their teaching and learning context, and their own attitudes and beliefs, which essentially aimed to distinguish between factors that might feasibly be changed or influenced by teachers or interventions (and/or even the students themselves) and factors that might not.

\subsection{Students'subject choices}

Secondary school students in England often consider science to be interesting, important for both school and wider life, and relevant for specific careers, although somewhat few students aspire to be scientists (DeWitt, Archer, \& Osborne, 2014; Jenkins \& Nelson, 2005). Differences are also apparent in students' choices, where girls, those from families with low incomes, and those from Black, Bangladeshi, and Pakistani backgrounds are less likely to study non-compulsory science subjects, while boys, those from families with high incomes, and those from Chinese and Indian backgrounds are more likely (Department for Education, 2011; Gill \& Bell, 2013; Homer, Ryder, \& Banner, 2014; Institute of Physics, 2014; Royal Society, 2008). Differences have been especially highlighted for chemistry and physics (Elias, Jones, \& McWhinnie, 2006; Springate, Harland, Lord, \& Wilkin, 2008).

Research has revealed that differences in studying choices are explained more by students' attitudes and beliefs than by their background, gender, or even their attainment, although it remains less clear how students' attitudes (and their wider aspirations) develop within their wider personal and educational contexts (DeWitt, Archer, \& Osborne, 2014; Author $1 \&$ Author 3, 2014). Prior reviews of research have nevertheless highlighted the importance of two attitudes, specifically students' (intrinsic) interest in a subject and their (extrinsic) perceived utility of a subject in leading to wider outcomes (Bates, Pollard, Usher, \& Oakley, 2009; Blenkinsop, McCrone, Wade, \& Morris, 2006; Cann, 2009; Department for Education, 2012; McCrone, Morris, \& Walker, 2005; Regan \& DeWitt, 2015). Recent research in England has reaffirmed the relevance of students' perceived utility of science and their interest in science to their intentions to study non-compulsory science across secondary school and into university, together with further factors including the personal value of science to their identity, their current confidence, their confidence in their future attainment, 
and influences from their family (Author 1 \& Author 3, 2014; Author 1 \& Author 3, 2016, Author 2, 2016).

On a wider level, science education has begun to consider various factors as an aggregated 'science capital', which disadvantaged students appear to have less of (Archer, Dawson, DeWitt, Seakins, \& Wong, 2015). 'Science capital' has been variously described as a conceptual explanatory perspective or as a way to collate science-specific forms of 'cultural capital', 'social capital', and other selected factors of relevance to aspirations (Archer, Dawson, DeWitt, Seakins, \& Wong, 2015; DeWitt, Archer, \& Mau, 2016). Science capital encompasses (for example) students' awareness of and engagement with people who work within science, students' extra-curricular engagement in science, students' own perceived utility or extrinsic value of science, and encouragement from teachers to study science (Archer, Dawson, DeWitt, Seakins, \& Wong, 2015). Nevertheless, research has highlighted that different dimensions of science capital have varying independent associations with students' aspirations (DeWitt, Archer, \& Mau, 2016), which highlights the benefit of future exploration into how these and other factors associate with students' aspirations.

\subsection{Educational practices and interventions}

While various factors can be identified as associating with students' studying intentions and choices, it remains somewhat unclear what educators can practically do in order to increase the numbers of students who might study science.

Some interventions have focused on students' attitudes towards science (Rosenzweig \& Wigfield, 2016). For example, emphasising the relevance of science and explaining the experiences and work of scientists has helped to increase students' interest in science (Bernacki, Nokes-Malach, Richey, \& Belenky, 2016; Hong \& Lin-Siegler, 2012; Hulleman \& Harackiewicz, 2009). Similarly, promoting the relevance and utility of science for students and parents has associated with higher science interest and attainment for students, and with students selecting courses in science (Harackiewicz, Rozek, Hulleman, \& Hyde, 2012; Rozek, Hyde, Svoboda, Hulleman, \& Harackiewicz, 2015). Specific interventions to promote the chemical sciences as a beneficial career, raise students' aspirations, and promote links between educational and other organisations have resulted in higher interest and career aspirations in students, but had greatest impact for those with existing aspirations (Lord, Straw, Springate, Harland, \& Hart, 2008; Lord, Straw, Hart, Springate, \& Harland, 2009). On 
a wider level, it remains somewhat unclear whether interventions focused on disadvantaged or other students can effectively achieve similar gains.

Various extra-curricular activities can be applied within science education, such as science clubs, visits to science or natural history museums, careers talks, and any number of other activities; some activities may be offered by schools, and students and their families may also engage in some activities independently. Engagement with extra-curricular activities has been associated with students studying science, to some extent, although the relevance remains somewhat unclear in direct comparison to other factors (Aschbacher, Li, \& Roth, 2010; Bennett, Lubben, \& Hampden-Thompson, 2013). Nevertheless, providing science clubs and ambassadors (volunteers from science-related fields who visit schools to give career talks, provide advice, and deliver demonstrations) has resulted in participating students reporting higher interest in science, interest in studying science further, and aspirations towards science careers, compared to other students (Straw \& Macleod, 2015).

Various approaches can also be applied within teaching/learning science in school. For example, 'inquiry-based' teaching/learning of science aims for students to apply a scientific method or approach during their studies, with a focus on practical experimentation and being facilitated by teachers rather than only focusing on teachers disseminating knowledge (Savelsbergh, et al., 2016). Inquiry-based learning has associated with higher attainment, for example, but so have numerous other teaching/learning approaches (Bennett, Lubben, \& Hogarth, 2007; Savelsbergh, et al., 2016; Schroeder, Scott, Tolson, Huang, \& Lee, 2007). Nevertheless, inquiry-based learning also appeares to associate with students' interest (Savelsbergh, et al., 2016). It may be beneficial to continue to explore how teaching approaches and classroom experiences may influence students' studying intentions (Abrahams, 2009; Hampden-Thompson \& Bennett, 2013; Wang, 2012).

In general, in remains less clear how extra-curricular activities and teaching approaches associate with students' aspirations, especially when compared to their attitudes and subjective beliefs about science. Further research could provide practical insight for teachers and educators, as some of these aspects could potentially be changed.

\section{Methods}

\subsection{Research aims}


In summary, students' science aspirations have been found to associate with their attitudes and beliefs, such as their interest in science, perceived utility of science, and their confidence in their own science abilities (Bøe \& Henriksen, 2015; Regan \& DeWitt, 2015). Wider aspects of students' lives, such as their home or extra-curricular engagement with science, may also be relevant (DeWitt, Archer, \& Mau, 2016). However, the relevance or influence of classroom experiences and teaching approaches remains less clear (Hampden-Thompson \& Bennett, 2013; Wang, 2012). Essentially, there remains uncertainty about which attitudes and/or aspects of life, and/or which teaching approaches and/or classroom experiences, associate with students' science studying intentions and so could be used to inspire more students to study science subjects. Additionally, few studies appear to have focused explicitly on students' choices to study chemistry, despite attention having been drawn to the area (Elias, Jones, \& McWhinnie, 2006; Springate, Harland, Lord, \& Wilkin, 2008). The Royal Society of Chemistry has highlighted that the number of students from disadvantaged backgrounds continuing with Chemistry is a priority area; the research in this paper thus seeks to add to the knowledge base about Chemistry participation amongst students from disadvantaged backgrounds or those that attend school catchments who predominantly serve a high proportion of students from disadvantaged backgrounds.

Accordingly, the research presented here considered what factors associated with students' science aspirations, and also students' specific aspirations towards chemistry. This aimed to complement and also to highlight potential similarities or differences with prior research that has mostly focused on physics and/or science in general (e.g. DeWitt, Archer, \& Osborne, 2014; Author $1 \&$ Author 3, 2014; 2016). The research also sought to provide a new perspective through focusing on a sample of disadvantaged students (who may or may not consider their studying choices in the same way as advantaged students), and hence to potentially inform where and how interventions might plausibly be focused.

Overall, the research aimed to distinguish the relative influences of students' backgrounds, aspects of their teaching and learning context, and their own attitudes and evaluations of science, which essentially aimed to distinguish any influences from factors that might feasibly be changed by teachers or interventions (and/or the students themselves) and from factors that might not.

\subsection{School and student sample}


The research presented here forms part of a wider project, which is researching barriers and enablers to science progression over five years. The results report on the first year.

The project focused on disadvantaged students, via selecting/sampling relatively lowattaining schools with student catchments from low socio-economic backgrounds, within specific geographical regions.

The sample considered in this paper covered 25 schools located across the East Midlands (9 schools), North West (7 schools), South East (5 schools), and West Midlands (4 schools) in England. Considering national attainment records for the 2014/2015 examination cohort for these schools, on average $46 \%$ of their students attained five or more GCSEs at grades $A^{*}$ to $C$ (including in both English and mathematics) and $42 \%$ were classified as disadvantaged (via eligibility for free school meals, essentially reflecting low family income). Comparatively, across England, excluding schools for those with special educational needs, $54 \%$ of students attained the equivalent GCSE standard and 28\% were classified as disadvantaged (Department of Education, 2016). Within the schools, 4780 students (2412 in Year 7 aged 11-12, and 2368 in Year 8 aged 12-13) were surveyed.

School-level indicators of disadvantage, such as the average number of students receiving free school meals, do not entail that all students are disadvantaged in that way. However, directly asking students questions about family income and/or receiving free school meals is not always feasible: students simply may not know the details of their family's income, and receiving free school meals or not may be a sensitive topic. Accordingly, and following from wider international studies, students were asked within the questionnaire about the 'number of books in the home' as a student-level proxy for socio-economic disadvantage, which similarly aimed to reflect family income and affluence (OECD, 2016). Nevertheless, any such indicator remains unavoidably approximate.

\subsection{Student questionnaires}

Students completed a questionnaire that measured various aspects of the students' backgrounds, their attitudes and beliefs concerning science and their learning at school, and various other areas, all with empirical and/or theoretical relevance to their educational progression and choices (given prior research/theory). For example, the measurement integrated theorised constructs/factors from the expectancy-value model of motivational choices, such as perceived utility and interest in science (Bøe, Henriksen, Lyons, \& 
Schreiner, 2011; Eccles, 2009), and theorised aspects or dimensions of 'science capital', such as engagement with extra-curricular science (Archer, Dawson, DeWitt, Seakins, \& Wong, 2015; DeWitt, Archer, \& Mau, 2016). The questionnaire design was informed by validated items/factors from previous national and international studies (Bøe, Henriksen, Lyons, \& Schreiner, 2011; OECD, 2016), and with further input and refinement via the educators/schools involved with the project.

The questionnaire items mainly used four-point disagreement/agreement scales (1 'strongly disagree', 2 'disagree', 3 'agree', and 4 'strongly agree'); as an exception, engagement and encouragement for extra-curricular activities were measured as frequencies (1 'never or hardly ever', 2 'sometimes', 3 'regularly', and 4 'often'). All of the items were scored so that high values represented a positive view (e.g. being interested, frequent extracurricular engagement, etc.).

Confirmatory factor analysis affirmed the underlying dimensions of each factor/construct; the internal consistency of the factors/constructs was also established via reliability analyses and considering the correlations between different items within the same construct. Essentially, this affirmed that the relevant items could be aggregated together into constructs/factors. The Cronbach's alpha coefficients for the constructs/factors, reflecting their internal consistency, were all found to be acceptable (i.e. above .7; Table 1). The factors/constructs were then calculated from the average of the individual items, which ensured that they reflected the same underlying four-point scales (Table 2).

Given the ages of the students, who studied 'science' as a specific subject (rather than as separate subjects for biology, chemistry, and physics), the questionnaire was (unavoidably) broadly orientated towards science in order to be accessible and easily interpretable; nevertheless, to potentially provide more insight, additional aspirations outcomes were orientated towards chemistry. As an aid, the questionnaire initially explained to the students that 'Chemistry is the science subject where you study materials such as solids, liquids and gases - what these are like and what they do. For example, in chemistry we see how solids like metals and liquids like water behave when they are heated or cooled. We also look at how substances react together to make new substances'. Students were accordingly asked about their future aspirations in science or chemistry (agreement or disagreement with, for example, 'I intend to continue to study science at an A-level or equivalent', with further items asking about aspirations towards studying science at university and with equivalent items asking about chemistry). In England, A-Level qualifications are non-compulsory and are 
undertaken at upper-secondary level (from age 16-17 to 17-18), but are required for admissions to university.

The considered items/factors, with example items, are summarised in Table $\mathbf{1}$ and are listed briefly as follows. The questionnaire covered students' background and context:

- The students' gender and the number of books at home (a common indicator used to broadly reflect socio-economic background);

- Students' home and background engagement in extra-curricular science activities (e.g. watching science media, attending a science club);

- Support and encouragement to continue with science post-16;

- Family encouragement towards, and shared family participation in, these extracurricular science activities, which reflected (together with extra-curricular activities themselves) theorised dimensions of science capital (Archer, Dawson, DeWitt, Seakins, \& Wong, 2015).

The questionnaire also covered students' perceptions of their experiences of their science lessons, as per international research (OECD, 2016), specifically focusing on:

- The extent that teachers highlighted the applications or wider relevance of science;

- The extent of students undertaking practical experiments (which included student-led activities and so encompassed the theoretical idea of 'inquiry-based' teaching/learning of science);

- The extent of interaction, debate, and sharing of scientific (and other) ideas within lessons.

The questionnaire also covered students' subjective attitudes and beliefs (Bøe, Henriksen, Lyons, \& Schreiner, 2011), specifically:

- The students' perceived utility of science, reflecting their extrinsic motivation towards science;

- The students' interest in science, reflecting their intrinsic motivation towards science;

- The students' self-concept beliefs, reflecting their confidence in their own abilities in science.

\subsection{Analytical approaches}


The associations between students' reported aspirations to study science further and other constructs/factors were considered through correlations and predictive modelling. Predictive modelling essentially reveals the independent association between a predictor and an outcome, while accounting statistically for any other constructs/factors within the model. Given that students within schools share the same environment, teachers, geographical location, and potentially other aspects of life or education, multi-level predictive modelling was selected for the final analysis to help account for any residual similarities between students within schools (Snijders \& Bosker, 2012). Otherwise, for example if ordinary-leastsquares linear regression was applied, residual similarities between students may entail lower standard errors associated with regression coefficients, which may then entail increased chances for significance to be observed (Snijders \& Bosker, 2012).

Students may not respond to questionnaire items for various reasons, but predictive modelling (by default) only considers students with responses for every included factor/construct. This can mean that an analytical sample differs in size and potentially in profile from an original sample, which can also reduce the power of statistical tests to reveal results. In order to avoid such issues, estimates of any missing responses were generated through multiple-imputation, which is considered to be one of the best contemporary approaches to handling missing responses (Peugh \& Enders, 2004; Rubin, 1996). Multipleimputation applies expectation-maximisation and saves multiple estimates ('plausiblevalues') of any missing responses, each with some randomly-added variation; analytical processes then combine results from across the multiple data sets to then separate the sources of variation (IBM, 2014; Rubin, 1976, 1987). All of the considered constructs/factors were used as input to this process. This process allowed 4601 students (out of 4780) to be consistently considered across the various predictive models; missing responses regarding students' gender (a binary variable) could not be imputed, which unavoidably reduced the analytical sample size, though only to a very small extent.

Sensitivity analysis highlighted that the fundamental findings (e.g. the relative predictive magnitudes) were the same regardless of whether multiple-imputation was applied or not. In order to maximise the number of considered students, the results therefore include estimates of any missing responses. Similarly, students in Years 7 and 8 were considered together (controlling for their year group within predictive modelling) to maximise the sample sizes (see the appended Supplementary Material for reliabilities, means, and correlations separated by year). 


\section{Results}

\subsection{Sample summary}

\subsubsection{Areas that students were most and least positive about}

On average (Table 2), students generally reported favourable views concerning science, especially for their perceived utility or extrinsic motivation for science, which reflected the way that science could help them with their future lives (the students reported, on average, a mean of 2.95, closest to 'agree' on the 1-4 scale). Students' interest in science was similarly positive (2.80). Students' self-concept beliefs (2.52) and overall aspirations towards science (2.50) were more ambivalent (both close to the mid-point of the 1-4 scale). Students' reported less-frequent engagement with extra-curricular science activities (1.70, closest to 'sometimes' on the 1-4 frequency scale) and family science capital (a mean of 1.89 on the 1-4 frequency scale).

\subsubsection{Correlations between the science and aspirations construct and other measures}

Bi-variate analysis (correlations) investigated which constructs/factors had the strongest associations with the science and chemistry aspirations items/factors (Table 3). The strongest association with science aspirations (considered as an aggregated factor/scale) was with extrinsic motivation $(\mathrm{R}=.67, \mathrm{p}<.001)$ followed by intrinsic motivation $(\mathrm{R}=.54, \mathrm{p}<.001)$; students' self-concept beliefs also had a positive but lesser magnitude of association with science aspirations $(\mathrm{R}=.36, \mathrm{p}<.001)$. Similar magnitudes of association were seen for the specific chemistry aspirations items (Table 3).

\subsection{Multivariate analysis: predicting students'science/chemistry aspirations}

Multi-level modelling was used to determine which constructs/factors independently explained variation in students' science/chemistry aspirations. Predictors were added in sequential steps: proportions of explained variance, deviance statistics, and chi-square 
likelihood ratio tests were used to consider how appropriate it was to use more complex models (i.e. whether complex models provided better fits than simpler models), together with examining the influence of individual predictors and their statistical significance (for brevity, the tables only report the predictive coefficients/significance and the overall explained/unexplained variance). Effect sizes from the multi-level models were reported as standardised coefficients.

Three dependent variables were considered: the science/chemistry aspirations construct/factor (Table 4); and two of the individual items that underpinned this construct, specifically, 'I intend to continue to study chemistry at an A-level or equivalent' (Table 5), and 'I intend to continue to study chemistry at university' (Table 6).

\subsubsection{Predicting students'aggregated science/chemistry aspirations}

Considering the construct reflecting students' aggregated aspirations to study and work within chemistry/science (Table 4), when only modelling students' background characteristics (Table 4, model 1), the following indicators/constructs were statistically significant (in order of descending effect size): students' family encouragement and shared participation in extra-curricular science activities (a family dimension of 'science capital'); students' socio-economic profile as measured by the number of books at home; and students' age (measured by year group). Subsequently (Table 4, model 2), students' participation in science extra-curricular activities was positively associated with their aspirations, in addition to the earlier predictors (while the magnitude of the family extra-curricular encouragement/ participation was reduced, but still significant).

When also considering students' experiences/perceptions of various science teaching approaches (Table 4, model 3), all were predictive of aspirations: teaching the applications of science had the strongest association, then teaching that used hands-on activities, and then (at a lower magnitude) teaching that involved interaction/debate. Students' background/home factors remained predictive.

When also considering students' perceived support and encouragement to study science, which covered encouragement from family, friends, and teachers (Table 4, model 4), this positively associated with aspirations. At this stage, some items/factors lost significance (specifically, family science capital and teaching that involved interaction/debate), suggesting 
that they associated with perceived support and encouragement which then primarily associated with aspirations.

When also considering students' extrinsic motivation (Table 4, model 5), this had the largest magnitude of association or effect size in explaining aspirations. Nevertheless, support and encouragement to study science, engagement in extra-curricular activities, teaching the applications of science, and hands-on science teaching remained significant, although at reduced magnitudes. However, the number of books at home (broadly reflecting family socio-economic background or affluence) lost significance at this stage; this suggested that disadvantaged socio-economic backgrounds may associate with lower extrinsic motivation towards science (lower beliefs that science may be useful to the students' studies and careers), which may then associate with lower aspirations (i.e. potentially explaining how disadvantage may have an effect on students).

When also considering students' intrinsic motivation or interest (Table 4, model 6), this had a positive association with aspirations. At this stage, teaching the applications of science, and hands-on science teaching, both lost significance, which suggested that these teaching aspects associated with students' interest which then associated with their aspirations. In addition (and surprisingly), interaction/debate in teaching became negatively predictive of aspirations (although at a minimal magnitude), suggesting that other complex patterns of association between factors may occur (which would need to be explored through more detailed and longitudinal modelling).

Finally (Table 4, model 7), students' self-concept beliefs were included, which positively associated with aspirations. Ultimately, the following independent positive associations with students' aspirations were found: extrinsic motivation (perceived utility of science), support and encouragement to study science, intrinsic motivation (interest in science), participation in extra-curricular science activities, self-concept beliefs (confidence in science abilities), and gender (where being a girl predicted higher aspirations). Overall, these predictive magnitudes of association were relatively low, except for extrinsic/utility, support/encouragement, and intrinsic/interest.

\subsubsection{Predicting students' intentions to study chemistry at A-level or equivalent}


Considering students' intentions to study chemistry at A-level or equivalent (Table 5), many similar results were observed (Table 5, model 1, model 2, model 3) but also with indications of differences.

The inclusion of students' reported support and encouragement highlighted that it was positively predictive of students' A-Level chemistry aspirations (Table 5, model 4), while many other predictors lost significance (specifically, interaction/debate in teaching, hands-on teaching, family science capital, and the number of books at home). It can be inferred that these aspects of students' home, background, and teaching context associate with perceived support and encouragement to study chemistry, which then associates with aspirations.

Similarly, the inclusion of students' extrinsic motivation highlighted that it was positively predictive of students' A-Level chemistry aspirations (Table 5, model 5), while teaching the applications of science lost significance. It can be inferred that teaching the applications of science associates with students' extrinsic motivation, which then associates with their aspirations.

Including further factors (Table 5, model 6 and model 7) broadly produced similar results as for students' overall aspirations. Ultimately (Table 5, model 7), the following independent positive associations with students' A-Level chemistry aspirations were found: extrinsic motivation (perceived utility of science), support and encouragement to study science, intrinsic motivation (interest in science), self-concept beliefs (confidence in science abilities), and participation in extra-curricular science activities.

\subsubsection{Predicting students' intentions to study chemistry at university}

Considering students' intentions to study chemistry at university (Table 6) produced relatively similar results. There were again indications that students' perceived support and encouragement explained the effects of many home, background, and teaching factors (Table 6, model 3). Similarly, intrinsic motivation appeared to explain the effects of teaching that highlighted the applications of science (Table 6, model 5). Ultimately (Table 6, model 7), the following independent positive associations with students' university chemistry aspirations were found: extrinsic motivation (perceived utility of science), support and encouragement to study science, intrinsic motivation (interest in science), participation in extra-curricular science activities, self-concept beliefs (confidence in science abilities), and gender (where being a girl predicted higher aspirations). 


\section{Discussion}

The presented research aimed to distinguish the relative influences of students' background, aspects of their teaching and learning context, and their own attitudes and beliefs, on the science and chemistry studying aspirations of a sample of students from less affluent backgrounds. Overall, the findings highlighted the strong relevance of students' extrinsic motivation (their perceived utility of science, beliefs that science qualifications will help access future careers and/or higher education). This coheres with, and extends, previous research in England that has considered mixed samples of students (Author 1 \& Author 3, 2014; Author 1, 2016). Additionally, the results suggest the new insight that many aspects of students' home and teaching context (including theorised dimensions of science capital) may not necessarily have independent associations with aspirations, but may have associations through students' perceptions and beliefs. For example, there were indications that teaching that explained the applications of science may associate with students' intrinsic and/or extrinsic motivation, which then mainly associated with aspirations. Nevertheless, longitudinal exploration remains necessary to confirm such implications.

Considered in more detail, the first key finding was that students' extrinsic motivation had the largest predictive association or effect size in explaining aspirations for all of the three different outcomes; students' other subjective beliefs, specifically their intrinsic motivation and their self-concept belief (students' confidence in their science abilities) were also independently predictive. This reaffirms findings from various prior studies undertaken in England (DeWitt, Archer, \& Osborne, 2014; Jensen \& Henriksen, 2015; Mellors-Bourne, Connor, \& Jackson, 2011; Author 1 \& Author 3, 2014; Author 2, 2016; Vidal Rodeiro, 2007). On a theoretical or conceptual level, science utility and interest in science have been conceptualised as important 'subjective values' relevant to students' choices, in addition to students' confidence (Eccles, 2009); students' utility beliefs are also theorised to be one dimension of 'science capital', although interest and confidence are not (Archer, Dawson, DeWitt, Seakins, \& Wong, 2015). The presented results perhaps suggest the benefit of further consolidation or work across theoretical/conceptual perspectives in order to gain insights (and/or potential refinement or clarification of theories or perspectives, such as their aims and how and why they differ). 
The second key finding was that, even after controlling for a range of background factors and key science education constructs/factors, there was still a positive association between students' engagement in science extra-curricular activities and their science/chemistry aspirations. This finding has practical relevance: although teachers cannot necessarily ensure that students read science books at home, they can help provide and support science clubs and other activities. Prior evaluations have highlighted that extracurricular activities, including science clubs, can indeed promote interest and aspirations (Lord, Straw, Springate, Harland, \& Hart, 2008; Lord, Straw, Hart, Springate, \& Harland, 2009; Straw \& Macleod, 2015). Either way, the sampled students reported that they had relatively infrequent engagement with extra-curricular activities, suggesting the potential for interventions and support.

The third key finding was that teaching approaches had significant associations with chemistry/science aspirations, although this was generally only observed when students' attitudes and beliefs were not accounted for. Nevertheless, teaching approaches are more feasibly under the control of educators, including providing students with the opportunity to take part in hands-on practical lessons, engage with science extra-curricular activities, and be shown the applications of science (and these all positively correlated with students' intentions to continue with non-compulsory science/chemistry). The detailed predictive models suggested that teaching factors may be beneficial through reflecting or associating with students' intrinsic and/or extrinsic motivation/values, which then associate with aspirations (although longitudinal modelling would be necessarily to clarify and confirm such patterns of association). Nevertheless, this finding coheres with implications from prior research: in chemistry education, a number of courses have included context-based teaching approaches, where everyday applications of chemistry form the starting point for the development of scientific ideas, and studies have suggested that these have helped foster students' interest (Bennett, Lubben, \& Hogarth, 2007; Savelsbergh, et al., 2016; Vaino, Holbrook, \& Rannikmäe, 2012).

The fourth key finding concerned the influence of students' backgrounds. Existing research has often highlighted that girls, on average, have reported lower aspirations towards science than boys (Gill \& Bell, 2013; Homer, Ryder, \& Banner, 2014). Perhaps surprisingly, the results highlighted that gender had no correlations with aspirations in this sample of students; however, girls were actually predicted to have slightly higher overall science aspirations than boys when accounting for their backgrounds and other beliefs within the predictive models. With reference to social disadvantage, the sample was not typical of 
schools in England (and was instead intentionally drawn from schools with larger concentrations of students from low socio-economic backgrounds). The results nevertheless show that students from higher socio-economic backgrounds (as measured by the number of books in the home) were found to have slightly higher aspirations when considered within the initial predictive models.

On a wider level, the models considered students' aggregated aspirations and also considered what factors were associated with chemistry-specific aspirations items. The results appeared broadly similar across these different outcomes. For example, students' exposure to teaching that included explaining the applications of science was positively associated with their intentions to study chemistry at A-level (or its equivalent) and at university. Similarly, positive associations between chemistry aspirations and engagement in science extra-curricular activities were seen. Such findings suggest that specific interventions for chemistry could feasibly consider similar approaches to interventions considering 'science' as a whole.

From the home/background factors, family encouragement and family science capital (shared engagement with extra-curricular science activities) was most strongly and positively associated with students' aspirations; subsequent models highlighted that both family science capital and actual participation in extra-curricular science activities were positively predictive, although family science capital ultimately lost significance. Both of these aspects reflect theorised dimensions of 'science capital' (Archer, Dawson, DeWitt, Seakins, \& Wong, 2015). On average, the sampled students reported somewhat low levels of encouragement/engagement. While this may appear an area for potential intervention, it may be difficult to influence families directly; instead, schools might concentrate on other potential influences that appear to have greater effect sizes. Engaging students with their learning could include, for example, giving them opportunities to spend time doing laboratory experiments and investigations and/or involve the teacher linking scientific concepts to everyday life outside of school.

\subsection{Limitations}

As in most research studies, some limitations were unavoidable. Fundamentally, the students studied 'science' as a specific subject (rather than studying biology, chemistry, and physics separately), so the questionnaire was primarily contextualised towards 'science' rather than 'chemistry', in order to be easily interpretable for students of these ages (within Year 7 and 
Year 8). Further research may benefit from considering biology, chemistry, and physics separately. Another methodological limitation was that measuring students' socio-economic status was only indirectly considered through the number of books at home, given that other questions may be sensitive or perceived as intrusive. On a wider level, the survey measured students' perceptions, which may vary from the views of others; specifically, the extent of the different teaching practices as perceived by the students might differ from extents as reported by teachers.

Given the cross-sectional survey, any causality cannot be robustly concluded; the findings show associations between the aspirations outcomes and the predictor variables, rather than causal relations. Given prior research and interventions, it appears plausible to infer that extra-curricular activities and interest can lead to aspirations towards science careers (e.g. Aschbacher, Li, \& Roth, 2010; Bennett, Lubben, \& Hampden-Thompson, 2013; Straw \& Macleod, 2015). Nevertheless, it is also plausible to infer that those who are interested and/or aspiring towards science may seek out and engage in extra-curricular activities. Any causality may also be reciprocal and occur in both directions over time (where higher extra-curricular engagement may foster higher aspirations while, concurrently, higher aspirations may also foster higher engagement in extra-curricular activities), and further research would be necessary to reveal any particular patterns.

On a wider level, students may be influenced by many other aspects of their lives and/or wider society. Specifically, students may have varying perceptions of what type of person they are and what type of people 'scientists' are, and they may have different approaches to handling any potential differences between themselves and any wider norms within the field of science (Aschbacher, Li, \& Roth, 2010; Eccles, 2009). For example, one person might feel that they 'fit' within contemporary norms within science, and hence may be more inclined towards science careers; someone else might feel that they differ from any norms, and hence may be more inclined towards careers in other fields; someone else might recognise that they differ from contemporary norms and still persevere within science, and they may even work towards changing the norms themselves. Additionally, significant life events, the actions or encouragement of particular people (such as role-models), and/or even pure chance may be relevant. Further research would be beneficial to explore and consider the influence of any wider influences, norms, stereotypes, and/or other potential aspects associated with studying and career choices within science. 


\subsection{Conclusions}

To conclude, students' science/chemistry aspirations most strongly associated with their extrinsic motivation (perceived utility towards science), their intrinsic interest in science, and their perceived support and encouragement to study science. Various other factors (including students' engagement, and family encouragement and family science capital, together with various science teaching approaches) were also relevant, but at lower magnitudes. The results suggested that family encouragement and shared participation in extra-curricular activities reflected or were closely connected to students' perceived support and encouragement to study science; similarly, teaching approaches in the classroom appeared to reflect or were closely connected to their extrinsic and intrinsic motivation towards science. The socioeconomic profile of students appeared to have little to no independent association with aspirations, when accounting for the students' subjective beliefs about science (the perceived usefulness of science to the future lives and their intrinsic interest in science), which suggested that socio-economic disadvantage may constraint students' aspirations through limiting their perceptions of the usefulness of science to the future lives.

Overall, the key message from this research is that to boost science and/or chemistry aspirations amongst students from disadvantaged backgrounds, teaching approaches that engage learners and raise their awareness of the benefits of having non-compulsory chemistry/science qualifications may be beneficial, through indirectly fostering their extrinsic and/or intrinsic motivations towards science. Students from disadvantaged backgrounds would also benefit from support and encouragement to continue with science and having access to science extra-curricular activities.

\section{Acknowledgements}

We are grateful to the Royal Society of Chemistry for funding the Chemistry for All project. We would also like to thank the schools and students who took part in this project, without whom the study would not have been possible, the Advisory Group and the other partner universities.

\section{References}


Abrahams, I. (2009). Does Practical Work Really Motivate? A study of the affective value of practical work in secondary school science. International Journal of Science Education, 31(17), 2335-2353. doi:10.1080/09500690802342836

ACOLA. (2013). STEM: Country Comparisons: International comparisons of science, technology, engineering and mathematics (STEM) education. Melbourne: Australian Council of Learned Academies.

Archer, L., Dawson, E., DeWitt, J., Seakins, A., \& Wong, B. (2015). “Science capital”: A conceptual, methodological, and empirical argument for extending Bourdieusian notions of capital beyond the arts. Journal of Research in Science Teaching, 52(7), 922-948. doi:10.1002/tea.21227

Aschbacher, P., Li, E., \& Roth, E. (2010). Is Science Me? High School Students' Identities, Participation and Aspirations in Science, Engineering, and Medicine. Journal of Research in Science Teaching, 47(5), 564-582. doi:10.1002/tea.20353

Bates, P., Pollard, E., Usher, T., \& Oakley, J. (2009). Who is Heading for HE? Young People's Perceptions of, and Decisions About, Higher Education. London: Department for Business, Innovation and Skills.

Bennett, J., Lubben, F., \& Hampden-Thompson, G. (2013). Schools That Make a Difference to Post-Compulsory Uptake of Physical Science Subjects: Some comparative case studies in England. International Journal of Science Education, 35(4), 663-689. doi:10.1080/09500693.2011.641131

Bennett, J., Lubben, F., \& Hogarth, S. (2007). Bringing science to life: A synthesis of the research evidence on the effects of context-based and STS approaches to science teaching. Science Education, 91(3), 347-370. doi:10.1002/sce.20186

Bernacki, M., Nokes-Malach, T., Richey, J. E., \& Belenky, D. (2016). Science diaries: a brief writing intervention to improve motivation to learn science. Educational Psychology, 36(1), 26-46. doi:10.1080/01443410.2014.895293

Blenkinsop, S., McCrone, T., Wade, P., \& Morris, M. (2006). How do young people make choices at 14 and 16? DfES Research Report 773. Nottingham: Department for Education and Skills.

Bøe, M. V., \& Henriksen, E. K. (2015). Expectancy-Value Perspectives on Choice of Science and Technology Education in Late-Modern Societies. In E. K. Henriksen, J. Dillon, \& J. Ryder (Eds.), Understanding Student Participation and Choice in Science and 
Technology Education (pp. 17-29). Dordrecht: Springer. doi:10.1007/978-94-0077793-4 2

Bøe, M. V., Henriksen, E. K., Lyons, T., \& Schreiner, C. (2011). Participation in science and technology: young people's achievement-related choices in late-modern societies. Studies in Science Education, 47(1), 37-72. doi:10.1080/03057267.2011.549621

Bosworth, D., Lyonette, C., Wilson, R., Bayliss, M., \& Fathers, S. (2013). The Supply of and Demand for High-Level STEM Skills. London: UK Commission for Employment and Skills.

British Academy. (2015). Count us in: Quantitative skills for a new generation. London: British Academy.

Cann, R. (2009). Girls' participation in post-16 mathematics: a view from pupils in Wales. Gender in Education, 21(6), 651-669. doi:10.1080/09540250802680065

Department for Education. (2011). Maths and science education: the supply of high achievers at A level. Research Report DFE-RR079. London: Department for Education.

Department for Education. (2012). Subject progression from GCSE to AS Level and continuation to A Level. Research Report DFE-RR195. London: Department for Education.

Department of Education. (2016, July 1). Compare school and college performance. Retrieved August 31, 2016, from Department of Education: https://www.compareschool-performance.service.gov.uk/download-data

DeWitt, J., Archer, L., \& Mau, A. (2016). Dimensions of science capital: exploring its potential for understanding students' science participation. International Journal of Science Education, 38, 2431-2449. doi:10.1080/09500693.2016.1248520

DeWitt, J., Archer, L., \& Osborne, J. (2014). Science-related Aspirations Across the PrimarySecondary Divide: Evidence from two surveys in England. International Journal of Science Education, 36(10), 1609-1629. doi:10.1080/09500693.2013.871659

Eccles, J. (2009). Who Am I and What Am I Going to Do With My Life? Personal and Collective Identities as Motivators of Action. Educational Psychologist, 44(2), 78-89. doi:10.1080/00461520902832368

Elias, P., Jones, P., \& McWhinnie, S. (2006). Representation of Ethnic Groups in Chemistry and Physics. London: The Royal Society of Chemistry and the Institute of Physics.

Gill, T., \& Bell, J. (2013). What Factors Determine the Uptake of A-level Physics? International Journal of Science Education, 35(5), 753-772. doi:10.1080/09500693.2011.577843 
Hampden-Thompson, G., \& Bennett, J. (2013). Science Teaching and Learning Activities and Students' Engagement in Science. International Journal of Science Education, 35(8), 1325-1343. doi:10.1080/09500693.2011.608093

Harackiewicz, J., Rozek, C., Hulleman, C., \& Hyde, J. (2012). Helping Parents to Motivate Adolescents in Mathematics and Science: An Experimental Test of a Utility-Value Intervention. Psychological Science, 23(8), 898-906. doi:10.1177/0956797611435530

Homer, M., Ryder, J., \& Banner, I. (2014). Measuring determinants of post-compulsory participation in science: a comparative study using national data. British Educational Research Journal, 40(4), 610-636. doi:10.1002/berj.3106

Hong, H.-Y., \& Lin-Siegler, X. (2012). How Learning About Scientists' Struggles Influences Students' Interest and Learning in Physics. Journal of Educational Psychology, 104(2), 469-484. doi:10.1037/a0026224

Hulleman, C., \& Harackiewicz, J. (2009). Promoting Interest and Performance in High School Science Classes. Science, 326(5958), 1410-1412. doi:10.1126/science. 1177067

IBM. (2014). IBM SPSS Missing Values 22. IBM. Retrieved April 1, 2016, from $\mathrm{ftp} / / /$ public.dhe.ibm.com/software/analytics/spss/documentation/statistics/22.0/en/clie nt/Manuals/IBM_SPSS_Missing_Values.pdf

Institute of Physics. (2014). Raising Aspirations in Physics: A review of research into barriers to STEM participation for students from disadvantaged backgrounds. London: Institute of Physics.

Jenkins, E., \& Nelson, N. (2005). Important but not for me: students' attitudes towards secondary school science in England. Research in Science and Technological Education, 23(1), 41-57. doi:10.1080/02635140500068435

Jensen, F., \& Henriksen, E. K. (2015). Short Stories of Educational Choice: In the Words of Science and Technology Students. In E. K. Henriksen, J. Dillon, \& J. Ryder (Eds.), Understanding Student Participation and Choice in Science and Technology Education (pp. 135-151). Dordrecht: Springer. doi:10.1007/978-94-007-7793-4_9

Lord, P., Straw, S., Hart, R., Springate, I., \& Harland, J. (2009). Evaluation of Chemistry for our Future: Extension Phase Report. Slough: National Foundation for Educational Research.

Lord, P., Straw, S., Springate, I., Harland, J., \& Hart, R. (2008). Evaluation of Chemistry for Our Future: Report on the first year of the evaluation (2007 - 2008). Slough: National Foundation for Educational Research. 
McCrone, T., Morris, M., \& Walker, M. (2005). Student Choices at Key Stage 3 - Literature Review. DfES Research Report RW68. London: Department for Education and Skills.

Mellors-Bourne, R., Connor, H., \& Jackson, C. (2011). STEM Graduates in Non-STEM Jobs. London: Department for Business, Innovation and Skills.

Mujtaba, T., \& Reiss, M. J. (2014). A survey of psychological, motivational, family and perceptions of physics education factors that explain 15-year-old students' aspirations to study physics in post-compulsory English schools. International Journal of Science and Mathematics Education, 12(2), 371-393. doi:10.1007/s10763-013-9404-1

National Science and Technology Council. (2013). Federal Science, Technology, Engineering, and Mathematics (STEM) Education: 5-Year Strategic Plan. Washington, DC: Executive Office of the President of the United States.

OECD. (2016). PISA 2015 Assessment and Analytical Framework: Science, Reading, Mathematic and Financial Literacy. Paris: OECD Publishing. doi:10.1787/9789264255425-en

Peugh, J., \& Enders, C. (2004). Missing Data in Educational Research: A Review of Reporting Practices and Suggestions for Improvement. Review of Educational Research, 74(4), 525-556. doi:10.3102/00346543074004525

Regan, E., \& DeWitt, J. (2015). Attitudes, Interest and Factors Influencing STEM Enrolment Behaviour: An Overview of Relevant Literature. In E. K. Henriksen, J. Dillon, \& J. Ryder (Eds.), Understanding Student Participation and Choice in Science and Technology Education (pp. 63-88). Dordrecht: Springer. doi:10.1007/978-94-0077793-4_5

Rosenzweig, E., \& Wigfield, A. (2016). STEM Motivation Interventions for Adolescents: A Promising Start, but Further to Go. Educational Psychologist, 51(2), 146-163. doi:10.1080/00461520.2016.1154792

Royal Society. (2008). Science and mathematics education, 14-19: A 'state of the nation' report on the participation and attainment of 14-19 year olds in science and mathematics in the UK, 1996-2007. London: The Royal Society.

Royal Society. (2014). Vision for science and mathematics education. London: The Royal Society.

Royal Society of Chemistry. (2014). Inspiring, engaging and expert: the formula for worldclass science and chemistry education. London: Royal Society of Chemistry.

Rozek, C., Hyde, J., Svoboda, R., Hulleman, C., \& Harackiewicz, J. (2015). Gender Differences in the Effects of a Utility-Value Intervention to Help Parents Motivate 
Adolescents in Mathematics and Science. Journal of Educational Psychology, 107(1), 195-206. doi:10.1037/a0036981

Rubin, D. (1976). Inference and missing data. Biometrika, 63(3), 581-592. doi:10.1093/biomet/63.3.581

Rubin, D. (1987). Multiple Imputation for Nonresponse in Surveys. New York: John Wiley \& Sons. doi:10.1002/9780470316696

Rubin, D. (1996). Multiple Imputation after 18+ Years. Journal of the American Statistical Association, 91(434), 473-489. doi:10.1080/01621459.1996.10476908

Savelsbergh, E., Prins, G., Rietbergen, C., Fechner, S., Vaessen, B., Draijer, J., \& Bakker, A. (2016). Effects of innovative science and mathematics teaching on student attitudes and achievement: A meta-analytic study. Educational Research Review, 19, 158-172. doi:10.1016/j.edurev.2016.07.003

Schroeder, C., Scott, T., Tolson, H., Huang, T.-Y., \& Lee, Y.-H. (2007). A Meta-Analysis of National Research: Effects of Teaching Strategies on Student Achievement in Science in the United States. Journal of Research in Science Teaching, 44(10), 1436-1460. doi:10.1002/tea.20212

Sheldrake, R. (2016). Students' intentions towards studying science at upper-secondary school: the differential effects of under-confidence and over-confidence. International Journal of Science Education, 38(8), 1256-1277.

doi:10.1080/09500693.2016.1186854

Snijders, T., \& Bosker, R. (2012). Multilevel Analysis: An Introduction to Basic and Advanced Multilevel Modeling (2nd ed.). London: SAGE Publications.

Springate, I., Harland, J., Lord, P., \& Wilkin, A. (2008). Why choose physics and chemistry? The influences on physics and chemistry subject choices of BME students. London: The Institute of Physics and the Royal Society of Chemistry.

Straw, S., \& Macleod, S. (2015). Evaluation of STEMNET's operations and impacts 20112015: Summary report. Slough: National Foundation for Educational Research.

Vaino, K., Holbrook, J., \& Rannikmäe, M. (2012). Stimulating students' intrinsic motivation for learning chemistry through the use of context-based learning modules. Chemistry Education Research and Practice, 13(4), 410-419. doi:10.1039/C2RP20045G

Vidal Rodeiro, C. (2007). A level subject choice in England: patterns of uptake and factors affecting subject preferences. Cambridge: Cambridge Assessment. 
Wang, M.-T. (2012). Educational and Career Interests in Math: A Longitudinal Examination of the Links Between Classroom Environment, Motivational Beliefs, and Interests. Developmental Psychology, 48(6), 1643-1657. doi:10.1037/a0027247

Wilson, R., Beaven, R., May-Gillings, M., Hay, G., \& Stevens, J. (2014). Working Futures 2012-2022. London: UK Commission for Employment and Skills. 


\section{Table 1: Items/factors and reliability}

\section{Factor}

Aspirations

Family science capital

Extra-curricular science activities

Teaching: explaining applications of science

Teaching: hands-on activities / student investigations

Teaching: interaction / debate

Support and encouragement to continue with

science post-16

Extrinsic motivation in science / utility

Intrinsic motivation in science / interest Science self-concept belief
Coverage / example items

Intentions to study science/chemistry at A-Level and/or university, and aspirations to science/chemistry careers

Family encouragement and shared participation in extra-curricular science activities (e.g. watching media, attending a science club)

Undertaking extra-curricular science activities (e.g. watching media, attending a science club)

'The teacher clearly explains the relevance of science concepts to our lives', 'The teacher uses examples of technological

application to show us how science is relevant to society'

'I spend time in the lab doing practical experiments', 'I am allowed to design my own experiments'

'The lessons involve all students' opinions about the topics', 'I am given the opportunity to explain my ideas'

'Someone in my family thinks that I should continue with science after my GCSEs', 'Someone in my family believes that science is important for my career'

is important for my career'
'Learning science is worthwhile for me because it will improve my chance of getting a job', 'I think science is a useful subject'

'Learning science is worthwhile for me because it will impto'
'Science is an interesting subject', 'I enjoy doing science'

'I am good at science', 'I do well in science tests'
Items

Reliability

Page 26 of 35 


\section{Table 2: Sample means and standard deviations}

Item/factor (1-4 scales unless noted)

Aspirations (aggregated scale)

A-Level chemistry aspirations (single-item) 'I intend to continue to study chemistry at an A-level or equivalent'

University chemistry aspirations (single-item) 'I intend to continue to study chemistry at university'

Year $(7 / 8)$

Gender (1=boy, 2= girl)

Gender $(1=$ boy, $2=$ git)

Family extra-curicular encouragement/participation

Extra-curicur scicor encouragen

Teaching: explaining applications of science

Teaching: hands-on activities / student investigations

Teaching: interaction / debate

Support and encouragement to continue with science post-16

Extrinsic / utility

Intrinsic / interest

$\begin{array}{rr}\mathrm{M} & \mathrm{SD} \\ 2.50 & .78\end{array}$

Self-concept beliefs

Notes: Missing values were estimated via multiple imputations. Standard deviations calculated via standard errors for the multiple imputation means. 


\section{Table 3: Correlations}

\begin{tabular}{|c|c|c|c|c|c|c|c|c|c|c|c|c|c|c|}
\hline Item/factor & $1 \mathrm{a}$ & $1 \mathrm{~b}$ & $1 \mathrm{c}$ & 2 & 3 & 4 & 5 & 6 & 7 & 8 & 9 & 10 & 11 & 12 \\
\hline 1a. Aspirations (aggregated scale) & 1 & & & & & & & & & & & & & \\
\hline 1b. A-Level chemistry aspirations & .83 & 1 & & & & & & & & & & & & \\
\hline 1c. University chemistry aspirations & .87 & .70 & 1 & & & & & & & & & & & \\
\hline 2. Year $(7 / 8)$ & .02 & .01 & -.01 & 1 & & & & & & & & & & \\
\hline 3. Gender $(1=$ boy, $2=$ girl $)$ & .02 & -.01 & .02 & .01 & 1 & & & & & & & & & \\
\hline 4. Books at home & .10 & .07 & .08 & -.06 & .07 & 1 & & & & & & & & \\
\hline 5. Family extra-curricular encouragement/participation & .30 & .24 & .24 & -.06 & -.02 & .11 & 1 & & & & & & & \\
\hline 6. Extra-curricular science activities & .33 & .26 & .27 & -.07 & -.10 & .08 & .64 & 1 & & & & & & \\
\hline 7. Teaching: explaining applications of science & .39 & .34 & .33 & -.05 & -.01 & .04 & .23 & .26 & 1 & & & & & \\
\hline 8. Teaching: hands-on activities / student investigations & .31 & .27 & .24 & -.04 & -.04 & .08 & .21 & .26 & .52 & 1 & & & & \\
\hline 9. Teaching: interaction / debate & .33 & .28 & .27 & -.04 & .01 & .05 & .20 & .22 & .60 & .57 & 1 & & & \\
\hline $\begin{array}{l}\text { 10. Support and encouragement to continue with science } \\
\text { post-16 }\end{array}$ & .52 & .42 & .43 & .03 & .05 & .13 & .36 & .31 & .33 & .26 & .31 & 1 & & \\
\hline 11. Extrinsic / utility & .67 & .54 & .51 & .04 & -.00 & .10 & .26 & .27 & .44 & .34 & .38 & .47 & 1 & \\
\hline 12. Intrinsic / interest & .54 & .44 & .43 & -.02 & -.07 & .09 & .30 & .33 & .60 & .53 & .59 & .41 & .56 & 1 \\
\hline 13. Self-concept beliefs & .42 & .35 & .35 & -.00 & -.12 & .14 & .26 & .33 & .37 & .36 & .39 & .39 & .41 & .53 \\
\hline
\end{tabular}

Notes: Missing values were estimated via multiple imputations. Significant Pearson $(\mathrm{R})$ coefficients $(\mathrm{p}<.05)$ are highlighted in bold. 
Table 4: Predicting: science/chemistry aspirations (aggregated factor/scale)

\begin{tabular}{|c|c|c|c|c|c|c|c|c|c|c|c|c|c|c|}
\hline \multirow[b]{3}{*}{ Item/factor } & \multicolumn{2}{|c|}{ Model 1} & \multicolumn{2}{|c|}{ Model 2} & \multicolumn{2}{|c|}{ Model 3} & \multicolumn{2}{|c|}{ Model 4} & \multicolumn{2}{|c|}{ Model 5} & \multicolumn{2}{|c|}{ Model 6} & \multicolumn{2}{|c|}{ Model 7} \\
\hline & Std. & & Std. & & Std. & & Std. & & Std. & & Std. & & Std. & \\
\hline & Effect & Sig. & Effect & Sig. & Effect & Sig. & Effect & Sig. & Effect & Sig. & Effect & Sig. & Effect & Sig. \\
\hline Intercept & NA & $<.001$ & NA & $<.001$ & NA & 0.60 & NA & 0.85 & NA & 0.01 & NA & 0.01 & NA & 0.00 \\
\hline Year group $(7,8)$ & 0.05 & 0.00 & 0.06 & $<.001$ & 0.07 & $<.001$ & 0.04 & 0.01 & 0.01 & 0.35 & 0.01 & 0.38 & 0.01 & 0.40 \\
\hline Gender (1=boy, $2=$ girl $)$ & 0.01 & 0.50 & 0.03 & 0.05 & 0.03 & 0.05 & 0.01 & 0.31 & 0.02 & 0.13 & 0.03 & 0.02 & 0.04 & 0.00 \\
\hline Books at home & 0.07 & $<.001$ & 0.07 & $<.001$ & 0.06 & $<.001$ & 0.03 & 0.04 & 0.01 & 0.54 & 0.00 & 0.79 & 0.00 & 0.88 \\
\hline Family extra-curricular encouragement/participation & 0.42 & $<.001$ & 0.21 & $<.001$ & 0.16 & $<.001$ & 0.03 & 0.21 & 0.02 & 0.45 & 0.01 & 0.58 & 0.01 & 0.51 \\
\hline Extra-curricular science activities & & & 0.26 & $<.001$ & 0.18 & $<.001$ & 0.14 & $<.001$ & 0.11 & $<.001$ & 0.09 & $<.001$ & 0.09 & $<.001$ \\
\hline Teaching: explaining applications of science & & & & & 0.23 & $<.001$ & 0.17 & $<.001$ & 0.06 & $<.001$ & 0.02 & 0.21 & 0.02 & 0.22 \\
\hline Teaching: hands-on activities / student investigations & & & & & 0.11 & $<.001$ & 0.08 & $<.001$ & 0.04 & 0.02 & 0.01 & 0.62 & 0.00 & 0.79 \\
\hline Teaching: interaction / debate & & & & & 0.07 & $<.001$ & 0.03 & 0.14 & -0.02 & 0.34 & -0.06 & $<.001$ & -0.06 & $<.001$ \\
\hline $\begin{array}{l}\text { Support and encouragement to continue with science } \\
\text { post-16 }\end{array}$ & & & & & & & 0.44 & $<.001$ & 0.26 & $<.001$ & 0.25 & $<.001$ & 0.24 & $<.001$ \\
\hline Extrinsic / utility & & & & & & & & & 0.49 & $<.001$ & 0.44 & $<.001$ & 0.43 & $<.001$ \\
\hline Intrinsic / interest & & & & & & & & & & & 0.19 & $<.001$ & 0.17 & $<.001$ \\
\hline Self-concept beliefs & & & & & & & & & & & & & 0.06 & $<.001$ \\
\hline Explained variance & $10.1 \%$ & & $13.3 \%$ & & $24.2 \%$ & & $35.9 \%$ & & $52.5 \%$ & & $54.1 \%$ & & $54.4 \%$ & \\
\hline Unexplained variance (residual) & $88.7 \%$ & & $85.6 \%$ & & $74.8 \%$ & & $63.8 \%$ & & $47.4 \%$ & & $45.7 \%$ & & $45.5 \%$ & \\
\hline Unexplained variance (school) & $1.2 \%$ & & $1.1 \%$ & & $1.1 \%$ & & $.3 \%$ & & $.1 \%$ & & $.2 \%$ & & $.2 \%$ & \\
\hline
\end{tabular}

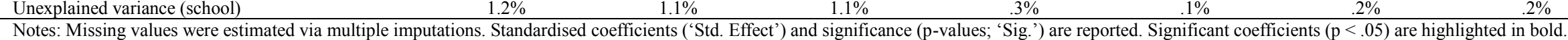


Table 5: Predicting: A-Level chemistry aspirations (single-item) 'I intend to continue to study chemistry at an A-level or equivalent'

\begin{tabular}{|c|c|c|c|c|c|c|c|c|c|c|c|c|c|c|}
\hline \multirow[b]{2}{*}{ Item/factor } & \multicolumn{2}{|c|}{ Model 1} & \multicolumn{2}{|c|}{ Model 2} & \multicolumn{2}{|c|}{ Model 3} & \multicolumn{2}{|c|}{ Model 4} & \multicolumn{2}{|c|}{ Model 5} & \multicolumn{2}{|c|}{ Model 6} & \multicolumn{2}{|c|}{ Model 7} \\
\hline & $\begin{array}{c}\text { Std. } \\
\text { Effect }\end{array}$ & Sig. & $\begin{array}{c}\text { Std. } \\
\text { Effect }\end{array}$ & Sig. & $\begin{array}{c}\text { Std. } \\
\text { Effect }\end{array}$ & Sig. & $\begin{array}{c}\text { Std. } \\
\text { Effect }\end{array}$ & Sig. & $\begin{array}{c}\text { Std. } \\
\text { Effect }\end{array}$ & Sig. & $\begin{array}{c}\text { Std. } \\
\text { Effect }\end{array}$ & Sig. & $\begin{array}{c}\text { Std. } \\
\text { Effect }\end{array}$ & Sig. \\
\hline Intercept & NA & $<.001$ & NA & $<.001$ & NA & 0.20 & NA & 0.12 & NA & 0.88 & NA & 0.78 & NA & 0.98 \\
\hline Year group $(7,8)$ & 0.02 & 0.17 & 0.03 & 0.10 & 0.03 & 0.05 & 0.01 & 0.36 & 0.00 & 0.83 & 0.00 & 0.80 & 0.00 & 0.79 \\
\hline Gender (1=boy, $2=$ girl $)$ & -0.01 & 0.66 & 0.01 & 0.52 & 0.01 & 0.55 & 0.00 & 0.70 & 0.00 & 0.89 & 0.01 & 0.55 & 0.01 & 0.28 \\
\hline Books at home & 0.04 & 0.00 & 0.03 & 0.01 & 0.03 & 0.02 & 0.01 & 0.48 & 0.00 & 0.78 & -0.01 & 0.59 & -0.01 & 0.39 \\
\hline Family extra-curricular encouragement/participation & 0.25 & $<.001$ & 0.13 & $<.001$ & 0.09 & 0.00 & 0.02 & 0.50 & 0.01 & 0.76 & 0.00 & 0.86 & 0.01 & 0.81 \\
\hline Extra-curricular science activities & & & 0.15 & $<.001$ & 0.10 & $<.001$ & 0.08 & $<.001$ & 0.06 & $<.001$ & 0.05 & 0.00 & 0.04 & 0.01 \\
\hline Teaching: explaining applications of science & & & & & 0.16 & 0.00 & 0.12 & 0.01 & 0.06 & 0.11 & 0.03 & 0.35 & 0.03 & 0.35 \\
\hline Teaching: hands-on activities / student investigations & & & & & 0.07 & 0.05 & 0.06 & 0.07 & 0.04 & 0.28 & 0.02 & 0.64 & 0.01 & 0.70 \\
\hline Teaching: interaction / debate & & & & & 0.04 & 0.02 & 0.01 & 0.50 & -0.01 & 0.37 & -0.04 & 0.00 & -0.05 & 0.00 \\
\hline $\begin{array}{l}\text { Support and encouragement to continue with science } \\
\text { post- } 16\end{array}$ & & & & & & & 0.27 & $<.001$ & 0.16 & $<.001$ & 0.15 & $<.001$ & 0.15 & $<.001$ \\
\hline Extrinsic / utility & & & & & & & & & 0.29 & $<.001$ & 0.26 & $<.001$ & 0.25 & $<.001$ \\
\hline Intrinsic / interest & & & & & & & & & & & 0.12 & $<.001$ & 0.10 & $<.001$ \\
\hline Self-concept beliefs & & & & & & & & & & & & & 0.05 & 0.02 \\
\hline Explained variance & $6.1 \%$ & & $8.0 \%$ & & $16.6 \%$ & & $24.2 \%$ & & $34.4 \%$ & & $35.5 \%$ & & $35.8 \%$ & \\
\hline Unexplained variance (residual) & $93.4 \%$ & & $91.5 \%$ & & $82.9 \%$ & & $75.6 \%$ & & $65.6 \%$ & & $64.4 \%$ & & $64.2 \%$ & \\
\hline Unexplained variance (school) & $.5 \%$ & & $.5 \%$ & & $.5 \%$ & & $.2 \%$ & & $.0 \%$ & & $.1 \%$ & & $.1 \%$ & \\
\hline
\end{tabular}

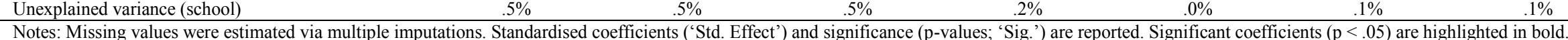


Table 6: Predicting: university chemistry aspirations (single-item) 'I intend to continue to study chemistry at university'

\begin{tabular}{|c|c|c|c|c|c|c|c|c|c|c|c|c|c|c|}
\hline \multirow[b]{2}{*}{ Item/factor } & \multicolumn{2}{|c|}{ Model 1} & \multicolumn{2}{|c|}{ Model 2} & \multicolumn{2}{|c|}{ Model 3} & \multicolumn{2}{|c|}{ Model 4} & \multicolumn{2}{|c|}{ Model 5} & \multicolumn{2}{|c|}{ Model 6} & \multicolumn{2}{|c|}{ Model 7} \\
\hline & $\begin{array}{c}\text { Std. } \\
\text { Effect }\end{array}$ & Sig. & $\begin{array}{c}\text { Std. } \\
\text { Effect }\end{array}$ & Sig. & $\begin{array}{c}\text { Std. } \\
\text { Effect }\end{array}$ & Sig. & $\begin{array}{c}\text { Std. } \\
\text { Effect }\end{array}$ & Sig. & $\begin{array}{c}\text { Std. } \\
\text { Effect }\end{array}$ & Sig. & $\begin{array}{c}\text { Std. } \\
\text { Effect }\end{array}$ & Sig. & $\begin{array}{c}\text { Std. } \\
\text { Effect }\end{array}$ & Sig. \\
\hline Intercept & NA & $<.001$ & NA & $<.001$ & NA & 0.40 & NA & 0.24 & NA & 0.90 & NA & 1.00 & NA & 0.81 \\
\hline Year group $(7,8)$ & 0.02 & 0.27 & 0.02 & 0.15 & 0.03 & 0.07 & 0.01 & 0.52 & -0.01 & 0.56 & -0.01 & 0.54 & -0.01 & 0.52 \\
\hline Gender $(1=$ boy, $2=\operatorname{girl})$ & 0.01 & 0.44 & 0.02 & 0.07 & 0.02 & 0.08 & 0.01 & 0.32 & 0.01 & 0.20 & 0.02 & 0.04 & 0.03 & 0.01 \\
\hline Books at home & 0.04 & 0.00 & 0.04 & 0.00 & 0.03 & 0.01 & 0.01 & 0.26 & 0.00 & 0.82 & $<.001$ & 0.99 & 0.00 & 0.74 \\
\hline Family extra-curricular encouragement/participation & 0.27 & $<.001$ & 0.13 & $<.001$ & 0.09 & 0.00 & 0.01 & 0.66 & 0.00 & 0.98 & 0.00 & 0.91 & 0.00 & 0.96 \\
\hline Extra-curricular science activities & & & 0.18 & $<.001$ & 0.12 & $<.001$ & 0.10 & $<.001$ & 0.08 & $<.001$ & 0.07 & $<.001$ & 0.07 & $<.001$ \\
\hline Teaching: explaining applications of science & & & & & 0.15 & $<.001$ & 0.12 & $<.001$ & 0.06 & 0.01 & 0.03 & 0.25 & 0.03 & 0.27 \\
\hline Teaching: hands-on activities / student investigations & & & & & 0.05 & 0.01 & 0.03 & 0.06 & 0.01 & 0.63 & -0.02 & 0.31 & -0.02 & 0.24 \\
\hline Teaching: interaction / debate & & & & & 0.06 & 0.01 & 0.03 & 0.19 & 0.01 & 0.78 & -0.03 & 0.15 & -0.03 & 0.09 \\
\hline $\begin{array}{l}\text { Support and encouragement to continue with science } \\
\text { post-16 }\end{array}$ & & & & & & & 0.29 & $<.001$ & 0.19 & $<.001$ & 0.18 & $<.001$ & 0.17 & $<.001$ \\
\hline Extrinsic / utility & & & & & & & & & 0.27 & $<.001$ & 0.24 & $<.001$ & 0.23 & $<.001$ \\
\hline Intrinsic / interest & & & & & & & & & & & 0.13 & $<.001$ & 0.12 & $<.001$ \\
\hline Self-concept beliefs & & & & & & & & & & & & & 0.05 & 0.00 \\
\hline Explained variance & $6.5 \%$ & & $8.8 \%$ & & $16.2 \%$ & & $24.0 \%$ & & $32.3 \%$ & & $33.6 \%$ & & $33.8 \%$ & \\
\hline Unexplained variance (residual) & $92.5 \%$ & & $90.2 \%$ & & $83.0 \%$ & & $75.7 \%$ & & $67.5 \%$ & & $66.2 \%$ & & $66.0 \%$ & \\
\hline Unexplained variance (school) & $1.0 \%$ & & $.9 \%$ & & $.8 \%$ & & $.3 \%$ & & $.2 \%$ & & $.2 \%$ & & $.2 \%$ & \\
\hline
\end{tabular}

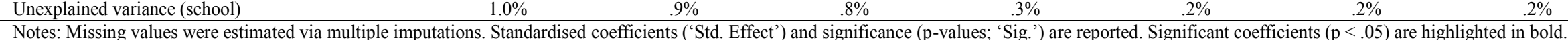




\begin{tabular}{|c|c|c|c|c|c|}
\hline & Coverage / example items & $\begin{array}{c}\text { Number of } \\
\text { items }\end{array}$ & $\begin{array}{l}\text { Reliability } \\
\text { (overall) }\end{array}$ & $\begin{array}{l}\text { Reliability } \\
\text { (Year 7) }\end{array}$ & $\begin{array}{c}\text { Reliability } \\
\text { (Year 8) }\end{array}$ \\
\hline Aspirations & Intentions to study science/chemistry at A-Level and/or university, and aspirations to science/chemistry careers & 6 & 0.92 & 0.91 & 0.92 \\
\hline $\begin{array}{l}\text { Family science capital (extra-curricular } \\
\text { encouragement) }\end{array}$ & $\begin{array}{l}\text { Family encouragement and shared participation in extra-curricular science activities (e.g. watching media, } \\
\text { attending a science club) }\end{array}$ & 2 & 0.75 & 0.74 & 0.75 \\
\hline Extra-curricular science activities & Undertaking extra-curricular science activities (e.g. watching media, attending a science club) & 4 & 0.80 & 0.80 & 0.80 \\
\hline $\begin{array}{l}\text { Teaching: explaining applications of } \\
\text { science }\end{array}$ & $\begin{array}{l}\text { 'The teacher clearly explains the relevance of science concepts to our lives', 'The teacher uses examples of } \\
\text { technological application to show us how science is relevant to society' }\end{array}$ & 5 & 0.84 & 0.84 & 0.84 \\
\hline $\begin{array}{l}\text { Teaching: hands-on activities / student } \\
\text { investigations }\end{array}$ & 'I spend time in the lab doing practical experiments', 'I am allowed to design my own experiments' & 4 & 0.76 & 0.76 & 0.75 \\
\hline Teaching: interaction / debate & 'The lessons involve all students' opinions about the topics', 'I am given the opportunity to explain my ideas' & 3 & 0.78 & 0.78 & 0.78 \\
\hline $\begin{array}{l}\text { Support and encouragement to continue } \\
\text { with science post- } 16\end{array}$ & $\begin{array}{l}\text { 'Someone in my family thinks that I should continue with science after my GCSEs', 'Someone in my family } \\
\text { believes that science is important for my career' }\end{array}$ & 6 & 0.87 & 0.87 & 0.87 \\
\hline Extrinsic motivation in science / utility & $\begin{array}{l}\text { 'Learning science is worthwhile for me because it will improve my chance of getting a job', 'I think science is a } \\
\text { useful subject' }\end{array}$ & 7 & 0.88 & 0.86 & 0.89 \\
\hline Intrinsic motivation / interest & 'Science is an interesting subject', 'I enjoy doing science' & 6 & 0.92 & 0.92 & 0.92 \\
\hline Science self-concept beliefs & 'I am good at science', 'I do well in science tests' & 7 & 0.90 & 0.89 & 0.90 \\
\hline
\end{tabular}




\section{Appendix B: Sample means and standard deviations, aggregated and per year}

Item/factor (1-4 scales unless noted)

Aspirations (aggregated scale)

A-Level chemistry aspirations (single-item) 'I intend to continue to study chemistry at an A-level or equivalent'

Overall (Year 7 and 8)

University chemistry aspirations (single-item) 'I intend to continue to study chemistry at university'

$\mathrm{M}$

$\begin{array}{ll} & \text { SD } \\ 2.50 & \\ 2.60 & \end{array}$

Year $(7 / 8)$

Gender (1=boy, 2=girl)

Family science capital

Extra-curricular science activities

Teaching: explaining applications of science

Teaching: hands-on activities / student investigations

Teaching: interaction / debate

Support and encouragement to continue with science post-16

Extrinsic motivation in science / utility

Intrinsic value/ interest

$2.45 \quad 1.15$

$7.50 \quad .50$
1.48

$\begin{array}{rr}1.48 & .50 \\ 2.78 & 1.32 \\ 1.89 & 1.21\end{array}$

1.89

$\begin{array}{ll}1.89 & 1.21\end{array}$

Science self-concept belief

$\begin{array}{ll}2.76 & .75 \\ 2.44 & .80\end{array}$

2.85

2.62

2.95

2.52

Notes: Missing values were estimated via multiple imputations. Standard deviations calculated via standard errors for the multiple imputation means.

\begin{tabular}{crcr} 
Year 7 & \multicolumn{3}{c}{ Year 8 } \\
\hline & SD & \multicolumn{1}{c}{ M } & SD \\
\hline 2.49 & .83 & 2.52 & .84 \\
2.59 & 1.37 & 2.60 & .93 \\
2.45 & 1.32 & 2.45 & 1.00 \\
7.00 & .00 & 8.00 & .00 \\
1.48 & .50 & 1.49 & .50 \\
2.86 & 1.34 & 2.71 & 1.35 \\
1.94 & 1.07 & 1.84 & 1.07 \\
1.75 & .77 & 1.66 & .67 \\
2.79 & .74 & 2.73 & .80 \\
2.47 & .72 & 2.41 & .78 \\
2.88 & .66 & 2.82 & .70 \\
2.60 & 1.06 & 2.64 & .87 \\
2.92 & .63 & 2.97 & .66 \\
2.82 & .75 & 2.78 & .76 \\
2.53 & .69 & 2.52 & .68 \\
& & &
\end{tabular}




\section{Appendix C: Correlations (Year 7 only)}

\begin{tabular}{|c|c|c|c|c|c|c|c|c|c|c|c|c|c|}
\hline Item/factor & $1 \mathrm{a}$ & $1 \mathrm{~b}$ & $1 \mathrm{c}$ & 2 & 3 & 4 & 5 & 6 & 7 & 8 & 9 & 10 & 11 \\
\hline 1a. Aspirations (aggregated scale) & 1 & & & & & & & & & & & & \\
\hline 1b. A-Level chemistry aspirations & 0.83 & 1.00 & & & & & & & & & & & \\
\hline 1c. University chemistry aspirations & 0.87 & 0.70 & 1.00 & & & & & & & & & & \\
\hline 2. Gender (1=boy, $2=$ girl $)$ & 0.01 & -0.02 & 0.00 & 1.00 & & & & & & & & & \\
\hline 3. Books at home & 0.10 & 0.07 & 0.07 & 0.10 & 1.00 & & & & & & & & \\
\hline 4. Family science capital & 0.33 & 0.25 & 0.25 & -0.01 & 0.09 & 1.00 & & & & & & & \\
\hline 5. Extra-curricular science activities & 0.36 & 0.28 & 0.28 & -0.09 & 0.05 & 0.62 & 1.00 & & & & & & \\
\hline 6. Teaching: explaining applications of science & 0.39 & 0.34 & 0.33 & -0.03 & 0.03 & 0.23 & 0.29 & 1.00 & & & & & \\
\hline 7. Teaching: hands-on activities / student investigations & 0.32 & 0.28 & 0.26 & -0.05 & 0.06 & 0.22 & 0.28 & 0.49 & 1.00 & & & & \\
\hline 8. Teaching: interaction / debate & 0.33 & 0.28 & 0.27 & 0.00 & 0.02 & 0.20 & 0.24 & 0.58 & 0.56 & 1.00 & & & \\
\hline $\begin{array}{l}\text { 9. Support and encouragement to continue with science } \\
\text { post-16 }\end{array}$ & 0.53 & 0.42 & 0.43 & 0.05 & 0.12 & 0.36 & 0.32 & 0.31 & 0.27 & 0.31 & 1.00 & & \\
\hline 10. Extrinsic motivation in science / utility & 0.67 & 0.54 & 0.52 & 0.00 & 0.09 & 0.28 & 0.29 & 0.43 & 0.35 & 0.37 & 0.47 & 1.00 & \\
\hline 11. Intrinsic value/ interest & 0.54 & 0.46 & 0.44 & -0.08 & 0.07 & 0.29 & 0.35 & 0.59 & 0.53 & 0.59 & 0.40 & 0.53 & 1.00 \\
\hline 12. Science self-concept beliefs & 0.45 & 0.38 & 0.37 & -0.09 & 0.13 & 0.27 & 0.32 & 0.38 & 0.39 & 0.40 & 0.39 & 0.43 & 0.55 \\
\hline
\end{tabular}

Notes: Missing values were estimated via multiple imputations. Significant Pearson $(\mathrm{R})$ coefficients $(\mathrm{p}<.05)$ are highlighted in bold. 
Appendix D: Correlations (Year 8 only)

\begin{tabular}{|c|c|c|c|c|c|c|c|c|c|c|c|c|c|}
\hline Item/factor & $1 \mathrm{a}$ & $1 \mathrm{~b}$ & $1 \mathrm{c}$ & 2 & 3 & 4 & 5 & 6 & 7 & 8 & 9 & 10 & 11 \\
\hline 1a. Aspirations (aggregated scale) & 1 & & & & & & & & & & & & \\
\hline 1b. A-Level chemistry aspirations & 0.84 & 1.00 & & & & & & & & & & & \\
\hline 1c. University chemistry aspirations & 0.87 & 0.71 & 1.00 & & & & & & & & & & \\
\hline 2. Gender $(1=$ boy, $2=$ girl $)$ & 0.03 & 0.01 & 0.03 & 1.00 & & & & & & & & & \\
\hline 3. Books at home & 0.10 & 0.08 & 0.08 & 0.04 & 1.00 & & & & & & & & \\
\hline 4. Family science capital & 0.29 & 0.23 & 0.24 & -0.02 & 0.13 & 1.00 & & & & & & & \\
\hline 5. Extra-curricular science activities & 0.31 & 0.24 & 0.26 & -0.10 & 0.11 & 0.66 & 1.00 & & & & & & \\
\hline 6. Teaching: explaining applications of science & 0.40 & 0.34 & 0.32 & 0.00 & 0.04 & 0.22 & 0.22 & 1.00 & & & & & \\
\hline 7. Teaching: hands-on activities / student investigations & 0.31 & 0.26 & 0.23 & -0.02 & 0.10 & 0.20 & 0.23 & 0.55 & 1.00 & & & & \\
\hline 8. Teaching: interaction / debate & 0.34 & 0.28 & 0.28 & 0.03 & 0.07 & 0.19 & 0.20 & 0.62 & 0.58 & 1.00 & & & \\
\hline $\begin{array}{l}\text { 9. Support and encouragement to continue with science } \\
\text { post-16 }\end{array}$ & 0.52 & 0.43 & 0.43 & 0.05 & 0.13 & 0.37 & 0.31 & 0.36 & 0.26 & 0.32 & 1.00 & & \\
\hline 10. Extrinsic motivation in science / utility & 0.67 & 0.55 & 0.51 & -0.01 & 0.11 & 0.25 & 0.26 & 0.45 & 0.33 & 0.39 & 0.48 & 1.00 & \\
\hline 11. Intrinsic value in science / interest & 0.54 & 0.44 & 0.43 & -0.05 & 0.11 & 0.28 & 0.31 & 0.61 & 0.53 & 0.60 & 0.43 & 0.58 & 1.00 \\
\hline 12. Science self-concept beliefs & 0.40 & 0.33 & 0.32 & -0.15 & 0.15 & 0.25 & 0.33 & 0.37 & 0.33 & 0.38 & 0.38 & 0.40 & 0.52 \\
\hline
\end{tabular}

Notes: Missing values were estimated via multiple imputations. Significant Pearson $(\mathrm{R})$ coefficients $(\mathrm{p}<.05)$ are highlighted in bold. 